\title{
Issue Management by the Ministry of Communication and Informatics in Minimizing Hoax During Covid-19 in Indonesia
}

\author{
Vicki Sofyani ${ }^{1}$ Roswita Oktavianti ${ }^{1 *}$ \\ ${ }^{1}$ Faculty of Communication, Universitas Tarumanagara, Jakarta 11440, Indonesia \\ "Corresponding author. Email: roswitao@fikom.untar.ac.id
}

\begin{abstract}
The pandemic of coronavirus disease (Covid-19) is an ongoing condition in the world, including Indonesia. Technological developments offer efficiency to each individual with free access and produce information on the mass media. However, not every published information is accurate. Information that is distributed to each individual needs to be validated with accuracy and clarified from the government's data. This study raises issues regarding issue management by the Ministry of Communication and Informatics Republic of Indonesia (Kominfo) in minimizing hoax during Covid-19. The hoax explosion urges public relations (PR) in Kominfo to act immediately before an individual is harmed by the hoax and will lead to a foul image and failure of Kominfo in carrying out their duties. This research uses a qualitative approach with a case study method. The research subject is Kominfo PR and the object of research is the activity of issue management in minimizing hoax during the Covid-19. Data collection and processing was carried out by interviewing techniques. This research shows that Kominfo PR focused on managing public communication and goes through all stages of the issue management process, namely issue identification, issue analysis, action planning stage, program implementation, and evaluation by artificial intelligent system (AIS) engine, mapping algorithms with AIS, implementing digital literacy, collaborating with penta helix, routine evaluation at all position level and content on social media.
\end{abstract}

Keywords: Issue management, public relations, hoax

\section{INTRODUCTION}

The Pandemic of Coronavirus Disease (Covid-19) is a condition that occurs in the world, including in Indonesia. The number of positive cases infected with Covid-19 in Indonesia from July 20, 2020, is ranked $9^{\text {th }}$ in Asia and $23^{\text {rd }}$ in the world [1].

The dissemination of information about the Covid-19 pandemic has been widely circulated throughout the mass media. However, not whole information in circulation is validated by facts. Technological developments offer efficiency to everyone in accessing and producing information in the mass media freely. This makes individuals faced with the spread of hoaxes that have touched almost all aspects in their life and the most worrying thing is the hoax explosion during the Covid-19 pandemic in the mass media, especially in online media platforms, which caused panic on the individual.

During the Covid-19 pandemic, the Ministry of Communication and Informatics of the Republic of Indonesia (Kominfo) noted that from January to August 8, 2020, 1,028 hoaxes were found spread on various online media platforms related to disinformation about Covid-19
[2]. One of the well-known and widespread hoaxes on social media is about consuming garlic is claimed to cure victims infected with the coronavirus [3]. For example, the South China Morning Post reported that a woman had to be hospitalized because she had a severe sore throat due to consuming 1.5 kilograms of raw garlic [4]. This case is extremely dangerous if there is no follow-up from the authorities.

Related to this, the government often urges individuals to not believe the news easily and validate it before consuming the news. According to the Minister of Communication and Informatics, Johnny G Plate, the development of hoax issues could harm Indonesia. The impact can vary, from the economic, industrial, and tourism sectors. Therefore, it is appealed to the public not to be affected by hoaxes about the coronavirus [5].

The main duties and functions of the Ministry of Communication and Information Technology are to formulate national policies, implementation policies, and technical policies in the field of communication and information technology which include post, telecommunications, broadcasting, information and communication technology, multimedia services and information dissemination. As a national information 
dissemination service, the hoax explosion that occurred urged Kominfo government Public Relations (PR) institutions to move quickly in minimizing hoax by managing issues before individuals are harmed by incorrect information and will lead to a decline in good image and failure of Kominfo in carrying out his job [6]. According to Coates, Jarrat and Heinz, issue management is an activity within an organization to identify emerging trends or issues that may affect organizational activities in the next few years, including in the short term, and to build organizational strategies to respond to them. One of Kominfo's PR tasks is to compile every government narrative and disseminate it to the public. According to Jefkins, PR is a planned communication, into and out between the company and all audiences to achieve goals and mutual understanding [7].

Kominfo PR is categorized as a government public relations. Government public relations is an institution that performs management functions in the field of information and communication that is persuasive, effective, and efficient, to create a harmonious and mutually beneficial relationship with the public through various public relations facilities to create a positive image and reputation of government agencies [8].

The spreading of information in the mass media is growing rapidly, especially information that is spread through online media platforms such as social media that is not monitored at first. Meanwhile, information that is distributed to each individual needs to be balanced with accurate data that has been clarified by the government quickly, so the information obtained by individuals is actual and hoax free. This is a challenge that must be carried out for Kominfo PR in implementing issue management quickly and being responsive to problems that occur in the public such as hoaxes during the Covid-19 pandemic.

Based on this background, the researcher formulated a problem, namely "how is issue management by the Ministry of Communication and Information Technology of the Republic of Indonesia in minimizing hoaxes during the Covid-19 pandemic?". The purpose of this study is to determine the issue management by the Ministry of Communication and Information Technology of the Republic of Indonesia in minimizing hoaxes during the Covid-19 pandemic.

\section{METHODS}

This research used a qualitative approach. According to Lexy J. Moleong, qualitative research is research that understands the phenomena experienced by research subjects such as behavior, perception, motivation, action holistically, describing words, and language in a special and natural context by utilizing various natural methods [9]. Researcher used this type of qualitative research because researcher wanted to dig up information about the management process of hoax issues during the Covid-19 pandemic by Kominfo PR. This process is known through the interview method with informants and the results are in the form of words. In this study, researcher used a case study of Kominfo PR to explore and find out the information needed by researcher in-depth regarding the problem under study.

The subject of this research is Kominfo PR. Then, the object of research studied was issue management activities in minimizing hoax issues during the Covid-19 pandemic.

The data collection and discovery techniques used by the researcher were semi-structured interviews with Ferdinandus Setu as the Head Bureau of Public Relations in Kominfo and Annisaa Bonita as the Online Media Public Relations of Kominfo.

The data processing technique in this study was to transcribe the verbatim data after interviews and analyze it by doing open coding and axial coding. This research was conducted in the midst of the Covid-19 pandemic so that interviews were conducted online using WhatsApp application facilities with voice calls and voice notes.

The data obtained by the researcher must be checked for validity and the data validity technique used by the researcher in this study is the observation triangulation technique, namely by making observations on social media owned by Kominfo. This is done so that researcher can obtain clear and accurate data.

\section{FINDINGS AND DISCUSSIONS}

According to Law Number 39 of 2008 concerning State Ministries, the Ministry of Communication and Information is an apparatus of the Government of Republic Indonesia in charge of affairs whose scope in information and communication. The Ministry of Communication and Information is led by a Minister of Communication and Information (Menkominfo) since 23 October 2019 by Johnny Gerard Plate. There is a Public Relations Bureau at Kominfo which is currently held by Ferdinandus Setu. Kominfo's PR main task is to implement and carry out good public communication with the community (https://www.kominfo.go.id/unit-kerja).

During the Covid-19 pandemic, the role and function of Kominfo PR focused more on public communication regarding the delivery of information about Covid-19 to the public. According to Ferdinandus Setu, there were three roles and functions of Kominfo PR during the Covid-19 pandemic. First, ensure the GPR or public communications related to Covid-19 can be communicated properly. Second, ensure that telecommunication networks in the 3T area (underdeveloped, outermost, and underdeveloped), especially health centers community and regional public hospitals related to the handling of Covid19 are built quickly so that the coordination process of the central and regional governments can be carried out properly. Third, prepare the 'PeduliLindungi' surveillance app, an application intended for tracing, tracking, and alerts for those who may go outside the house and be in a crowd where one of the individuals has been exposed to Covid-19. In delivering information about Covid-19, all communication channels are considered important by Kominfo PR so that information is right on target and 
easily understood by the public. All the channels referred to include television, print media, online media, offline meetings through folk performances. In building a relationship to get mutual benefits and understanding between institutions and public, the existence of establishing relationships is very important to do. Relationships such as doing quizzes and doing giveaways on the Kominfo official social media account. Kominfo is registered in various social media, namely Instagram, Twitter, Facebook, and Youtube.

In delivering information about Covid-19 to the public, the information was made by Kominfo based on information submitted by the Ministry of Health (Kemenkes). Kominfo PR uses various methods so that information is prepared properly and attractively, such as the publication of a routine magazine by Kominfo called 'Kominfo Next' and through the kominfo.go.id website. Various ways of conveying information are carried out so that the public and the Ministry of Communication and Information are prevented by misunderstood.

"Kominfo, for example, we even published our routine magazine 'Kominfo Next', almost 4 months edition specifically discussing the issue of Covid-19. We distribute this magazine to 514 cities in the country, we also convey it to the Public Relations Bureau of the Ministry of Institutions in Indonesia, so we print the physical ones above 600 copies of which we distribute to almost everyone who needs it and we also present them through the kominfo.go.id website. So the information is prepared based on the correct information submitted by the Ministry of Health, the Covid Task Force, all of it we compile and present attractively through our channels so that we hope not to harm the public, and not to harm the government, especially the Ministry of Communication and Information." - Ferdinandus Setu

According to Ferdinandus Setu, many hoaxes have been stamped with hoaxes and clarified but sometimes they reappear. The types of hoax issues referred to include clickbait, no source, exaggeration, hoaxes that pick-up news from decades ago and even grab news from other countries. Therefore, the implementation of digital literacy is considered important as a step to anticipate hoax issues that have previously been resolved but have the potential to recur. Regarding the handling of the Covid-19 hoax issue, Kominfo PR does not stand alone. There is a collaboration between several parties or departments called "Penta Helix" by Johnny. G Plate, Minister of the Ministry of Communication and Information of the Republic Indonesia. Penta helix means cooperation between five parties, namely the government, academics, Indonesian Parliament, journalists, and the public in recovering Covid-19 in the country. The cooperation is carried out in the form of compliance with the $3 \mathrm{M}$ program (maintaining distance, wearing masks, washing hands) which is made by the government to all parties, especially the community to accelerate the break-in Covid-19 chain. According to Ferdinandus Setu, the most dangerous Covid19 hoax issue is a conspiracy theory created by certain parties to discredit the government. This action makes the public feel that the government has failed in dealing with Covid-19. The existence of a conspiracy theory causing people to disbelieve in the existence of Covid-19 which then doubts the swab test and vaccine. In fact, according to him, there could be people who have spread hoaxes that vaccines are not halal (refers to action or behaviour that is permissible in Islam) and so on. People who do not believe in Covid-19 cause them not to wear masks, not wash their hands, not keep their distance, and not avoid crowds. Even later when the vaccine is available, they may not want to be vaccinated. Meanwhile, according to Annissa Bonita, the most dangerous hoax issue is a hoax that has no clarification because it is misleading.

"The characteristics and types of hoaxes that are most dangerous to society are hoaxes that have no clarification. For example, there is a hoax A but they have been looking for the information but they have not found the answer so that can be dangerous so why do some of us tell you this is a hoax, this is not a hoax, this is a clarification, one of which is so as not to mislead them anyway." - Annisaa Bonita

Issue management is a proactive process in managing issues, trends, or potential events, external and internal, which have a negative or positive impact on the organization and make issues an opportunity to improve the company's reputation. Efforts to manage issues are carried out by monitoring, identifying, analyzing, making strategic policies at the management level, implementing policies as actions to anticipate issues, and evaluating the impact of policies to support the continuity of company activities [10]. In this study, researcher used the issue management process theory according to Johston et al. There are five stages of issue management activities, namely as follows [11]:

\subsection{Issue Identification}

At this stage, it is necessary to identify issues based on categories such as type of issue, source, geographic scope, level of importance, and others. Issue identification is carried out in several ways, including research such as public opinion polls, monitoring, and media news clippings, and establishing relationships via the internet through various available social media. The types of hoax issues found by Kominfo consist of click-bait, without source, exaggeration, hoaxes that pick-up news from decades ago, and even grab news from other countries. PR Kominfo identified hoax issues using the Artificial Intelligent System (AIS) machine by the AIS Kominfo team. Then the results of the identified hoax issues will be clarified, stamped with hoaxes, and distributed to the Kominfo.go.id website and various Kominfo social media accounts such as Twitter, Facebook, and Instagram. The social media information content is fully managed and edited by the online media PR team of Kominfo. 


\subsection{Issue Analysis}

At this stage, issues are determined based on the type of issue that is predicted to have an impact on the organization. Issue analysis aims to find out the true sources, causes, and issues. Issues of hoaxes, disinformation, and malinformation regarding Covid-19 were analyzed using algorithmic mapping by the AIS Kominfo machine. This is then predicted by Kominfo PR whether the issue has the potential to harm the institution and the public or vice versa.

\subsection{Strategy Change Issues (Action Planning Stage)}

At the issue change strategy stage, the formulation of programs is carried out by the organization to respond to issues including formulating alternative strategies for changing issues. Educational literacy as a preventive step by Kominfo PR in minimizing the hoax issue of Covid-19 at this stage. Educational literacy is carried out by conveying to the public that all disseminated information in mass media is not all true or valid. Then, Kominfo Online Media PR conducts information publicity on social media about other interesting information besides Covid-19 so that information is balanced.

\subsection{Program Implementation (Issue Action Program)}

At this stage, an integrated communication program effort is made, namely by integrating all organizational components to carry out the three stages above. The public relations communication strategy is involved and consistent with the strategy of other departments such as marketing, finance, or human resources. The penta helix collaboration is implemented by Kominfo PR in the program implementation stage. This is a collaboration between five parties, namely the government, academics, the Indonesian Parliament, journalists, and the public in the recovery of Covid-19 in the country. In this collaboration, Kominfo PR collaborates with the central government in ensuring that telecommunication networks in disadvantaged, frontier, and outermost (3T) areas, especially public health centers and regional public hospitals, are accessible by the internet. Kominfo prepared the application "PeduliLindungi", an application aimed at tracing, tracking, and alerting individuals in a crowd, one of which has been exposed to Covid-19 with PT. Telkom and State-Owned Enterprises (BUMN) are supported by the National Disaster Mitigation Agency (BNPB) and the Ministry of Health (Kemenkes). Kominfo also helped BNPB prepare the covid19.co.id website. It is hoped that the community can work together in following and obeying programs made by the government such as 3M: maintaining distance, wearing masks, and washing hands.

\subsection{Evaluation}

To find out whether the program is running according to organizational goals, an evaluation process is required. Organizations need to compare whether the program implemented is as planned so that the issue does not become a crisis. The method used is the same as the research carried out in the first stage above because the public relations function is a continuous process. Evaluation is carried out routinely by Kominfo PR in handling programs that have been initiated. The evaluation was carried out at various levels such as the PR level, the Secretary-General level, to the Minister Johnny G. Plate level. The purpose of this evaluation is to find out whether the program regarding the handling of the Covid-19 hoax issue has been running well or not. Then, there is an evaluation of Kominfo's social media content by Kominfo Online Media PR which is held at the beginning of every month. The purpose of the evaluation is to find out what type of content has the highest and lowest performance in the context of public interest presented by Kominfo. According to Hallahan, hoaxes are information conveyed from user to user without verification of facts and verification of the source [12].

The type of hoax during the Covid-19 pandemic that is called the most dangerous hoax is a global conspiracy theory. Realizing that the public in Indonesia still easily believes and is provoked by hoax issues, the existence of those who believe in this theory causes public distrust in facing life in the real world about the existence of Covid-19 around them. Therefore, hoaxes like this one that endangers the nation and state are predicted to slow down efforts to break the Covid-19 chain in the country compared to other countries. This makes Kominfo PR ready to counter, clarify, and educate the public to not believe in these hoaxes. An example of hoax during the Covid-19 pandemic that was spread among the public via social media platform, Facebook, was about the coronavirus being transmitted through mosquito bites. In the narrative, it is stated that a mosquito that bites an individual infected with corona then bites another individual so the virus can infect that individual.

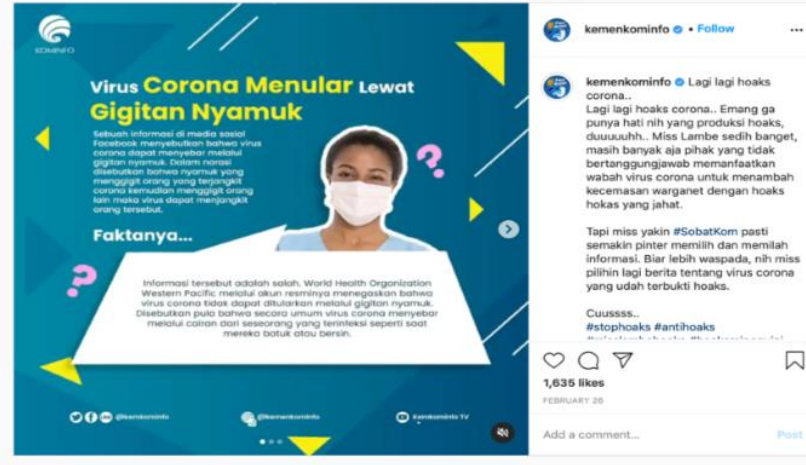

Figure 1 Screenshot of kominfo post on instagram (Source: https://www.instagram.com/kemenkominfo/) 
In fact, this information is neither true nor false. The World Health Organization Western Pacific emphasizes that the coronavirus cannot be transmitted through mosquito bites. In general, this virus is spread through fluids from infected individuals such as when they cough or sneeze. This hoax certainly caused public unrest and misunderstanding. Kominfo tries to be proactive in clarifying hoax content spread on social media. Kominfo works hard to identify and clarify hoaxes circulating in the public. Therefore, Kominfo immediately takes care and clarification through the Kominfo.go.id website channel in the publication section of reports on hoax issues and Kominfo social media such as Instagram, Facebook, Twitter, and Youtube. Publications related to the hoax clarification issue included with the correct explanation.

\section{CONCLUSION}

The issue management applied by Kominfo PR in minimizing hoaxes during the Covid-19 pandemic focuses on managing public communication to the public. Its management is based on Johston et al's issue management process, which consists of five stages of issue management activities, namely issue identification, issue analysis, issue change strategy, program implementation, and evaluation. At this stage of issue management, Kominfo carries out all five methods. First, identify hoax issues through an Artificial Intelligent System (AIS). Second, perform an issue analysis with mapping algorithmically by the AIS Kominfo machine. Third, carry out a strategy to change issues by implementing digital literacy. Fourth, implementing the program in collaboration with the Penta Helix consisting of five parties, namely the government, academics, Indonesian Parliament, journalists, and public. And fifth, conducting routine evaluations at various levels of positions at Kominfo as well as evaluating social media content to ensure whether the handling of the Covid-19 hoax issue has been going well.

\section{ACKNOWLEDGMENT}

The researcher expresses her gratitude for the availability of informants to provide the information needed by researcher and lectures of the Faculty of Communication Sciences at Tarumanagara University who have taught many things to researcher.

\section{REFERENCES}

[1] Worldometers, "Coronavirus Country Indonesia," 11 September 2020. [Online]. Available: https://www. worldometers.info/coronavirus/country/indonesia/.
[2] B. Mufarida, "Okezone.com," 23 September 2020. [Online]. Available: https://nasional.okezone.com/read/ 2020/08/12/337/226.

[3] F. Anwar, "detik.com," 2020 January 27. [Online]. Available: https://health.detik.com/berita-detikhealth/ d4875552/viral-bawang-putih-sembuhkan-viruscorona-ahli-vaksin-pastikan-hoax.

[4] B. Online, "bbc.com," 10 March 2020. [Online]. Available: https://www.bbc.com/indonesia/indonesia51801454.

[5] L. Rizkinaswara, "aptika.kominfo.go.id," 3 February 2020. [Online]. Available: https://aptika.kominfo.go.id/ 2020/02/kominfo-imbau-masyarakat-tidak-terpengaruhhoaks-virus-corona/.

[6] Kominfo, "kominfo.go.id," 11 September 2020. [Online]. Available: https://www.kominfo.go.id/profil.

[7] Jeffrey and A. Junaedi, "Kegiatan Public Relations Vottro Coffee and Bar dalam Menjaga Loyalitas Customer Vottro Coffee and Bar," Jurnal Prologia, vol. 3, no. 1, p. 143, 2019.

[8] Suprawoto, Government Public Relations: Perkembangan dan Praktik di Indonesia, Jakarta: Prenada Media Group, 2018.

[9] Mamik, Metode Penelitian Kualitatif, Sidoarjo: Zifatama Publisher, 2015.

[10] Prayudi, "Manajemen Isu Krisis," LPPM UPN Veteran Yogyakarta, Yogyakarta, 2016.

[11] R. Kriyantono, Public Relations, Issue \& Crisis Management Pendekatan Critical Public Relations, Etnografi Kritis \& Kualitatif Edisi 2, Jakarta: Kencana, 2014.

[12] Puspitasari, Komunikasi Krisis Strategi Mengelola dan Memenangkan Krisis, Jakarta: Libri, 2016. 